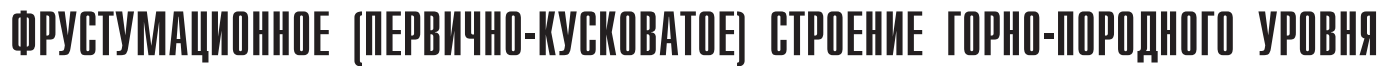

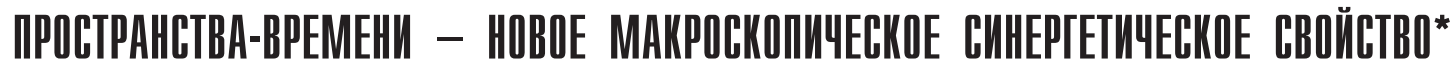

\author{
М. Ю. Поваренных, Е. Н. Матвиенко ${ }^{1}$, С. Ю. Янсон ${ }^{2}$ \\ ${ }^{1}$ Минералогический музей им. А. Е. Ферсмана РАН, Москва \\ ematvienko@mail.ru, \\ ${ }^{2}$ Санкт-Петербургский государственный университет, Санкт-Петербург \\ jansn.sv@gmail.com
}

Развитие в синергетическом смысле идей В. И. Драгунова и Д. В. Рундквиста об элементарных ячейках горных пород и академика М. А. Садовского о дискретности геофизической среды («естественной кусковатости») привело к установлению нового макроскопического горно-породного явления - первичной кусковатости, или фрустумации (от латинского «фрустум» - кусок), сначала для простых по минеральному составу и генезису, а затем и для полиминеральных и сложных по генезису горных пород. Предпосылки этого содержатся в работах С. М. Бескина, А. Г. Жабина, И. С. Делицина, А. Н. Никитина, О. А. Суставова, Н. 3. Евзиковой, В.В.Индутного и М. Ю. Поваренных, а ещё ранее - в статье Д. С. Коржинского о локальном («мозаичном») равновесии в неравновесных геологических процессах и в некоторых работах Ф. Ю. Левинсона-Лессинга.

Для выявления петрологической сущности фрустумации горных пород проведён комплекс разномасштабных исследований (от нано- до дециметрового уровня) наиболее простых по минеральному составу и генезису пород с использованием как традиционных минералого-петрографических методов, так и нейтронографического изучения текстур (метод малоуглового рассеяния нейтронов SANS), лазерно-ультразвуковой эхоскопии, УЗИ-томографии, УФ-люминесценции и сканирующей электронной микроскопии.

Ключевые слова: первичная кусковатость, фрустумация горных пород, нейтронографическое изучение текстур, лазерноультразвуковая эхоскопия, УЗИ-томография, УФ-люминесценция, сканирующая электронная микроскопия.

\section{FRUSTUMATIONAL (PRIMARY LUMPINESS PRESENCE) INNER FABRIC OF NATURAL ROCK LEVEL OF SPACE TIMINNESS - A NEW MACROSCOPIC SYNERGETIC FEATURE*}

\author{
M. Yur. Povarennykh, E. N. Matvienko', S. Yu. Yanson ${ }^{2}$ \\ ${ }^{1}$ Fersman Mineralogical museum RAS, Moscow \\ ${ }^{2}$ Sankt-Petersburg State University
}

Development in synergetic sense of the ideas of V. I. Dragunov and D. V. Rundqvist on the rocks unit cells and Academician M. A. Sadovsky on the geophysical medium discreteness («natural lumpiness») has led to the establishment of a new rock macroscopic stereological phenomenon - primary lumpiness, or frustumation (from Latin frustum - lump) firstly in rock samples with simple mineral composition and genesis, and later in rocks with polymineral composition and polygenic. Preconditions of this rock phenomenon discovery are contained in the works of S. M. Beskin, A. G. Zhabin, I. S. Delitsyn, A.N. Nikitin, O. A. Sustavov, V. V. Indutny and M. Yur. Povarennykh, and much earlier in the works of D. S. Korzhinskiy on the local («mosaic») equilibrium during disequilibrium natural geological processes and several works of F. Yu. Levinson-Lessing.

In order to reveal the petrophysical essence of the rock frustumation, we successfully conducted a complex of different scale investigations (from nano- to decimeter levels) of rocks with simple mineral composition and genesis with the help of traditional mineralogical-petrographical methods (polarization microscopy, UV-luminescence, X-ray- and microprobe analyses) as well as neutronographic investigation of rock fabric, laser-ultrasonic echoscopy, ultrasonic tomography, and scanning electron microscopy.

Kew words: primary lumpiness, frustumation of rocks, neutronographic investigation of rock fabric, laser-ultrasonic echoscopy, ultrasonic tomography, ultra-violet luminescence, scanning electron microscopy.

Мир не может быть без границ, без разбиений... Иоганн Петер Густав Дирихле (1805-1859)

\section{Введение}

Идея о сложении горной породы не только минеральными зёрнами, но и закономерными агрегатами минеральных зёрен, минимальными по размерам, трансляцией которых при помощи симметрийных (или гомологических) операций возможно воспроизвести её целиком («элементарными ячейками»), была высказана еще в 1972 г. [4]. К выводу о сушностном значении при классификации гранитов их «макрофизиографии» («структурной формулы») пришли С. М. Бескин, В. Н. Ларин и Ю. Б. Марин [1]. Ими была феноменологически установлена закономерная приуроченность определённого типа редкометалльного оруденения к гранитам трёх макрофизиографических типов. Закономерную агрегативность зёрен кварца в мономинеральных кварцевых породах (наличие устойчивых ансамблей из не менее чем двух десятков его зёрен), начиная от осадочных несцемен-

${ }^{*}$ Статья посвящена памяти и написана в развитие идей замечательного советского минералога - Аркадия Григорьевича Жабина (1934-2007) - одного из создателей теории онтогении минералов и агрегатов.

Примечание редакции: печатается в порядке дискуссии. Printed in order of discussion. 
тированных песков и песчаников до метаморфогенных кварцитопесчаников, установил И. С. Делицин $[8,9]$. Подобные же результаты наблюдений взаимной ориентировки кварцевых зёрен и образования закономерных агрегатов в мономинеральных кварцевых жилах опубликованы в работах $[18,37]$. Попытки визуализировать пространственную регулярность («аналогичную кристаллической решётке в кристаллах минералов») в гранитах и ряде других горных пород с помощью дифракции субмиллиметрового радиоволнового излучения с $\lambda=2-4$ мм предпринимались Р. Л. Бродской [2, 3].

В более общем плане академиком М. А. Садовским высказывалась идея о дискретности геофизической среды («естественной кусковатости»), для уровня горных пород выражающаяся в наблюдении квантования размеров продуктов их разрушения взрывом, и была установлена так называемая иерархическая шкала кусковатости с «преимущественными» размерами кусков [3234]. Похожие выводы об иерархичности структурной организации геологических тел высказаны Н. 3. Евзиковой и нами [11, 19-29, 56-58]. Д. С. Коржинским [16] выдвинуто положение о локальном («мозаичном») равновесии, реализующемся в неравновесных природных геологических процессах (не конкретизированное, впрочем, в минерально-структурном плане и без указаний на возможность его визуализации в горных породах).

С помощью минералого-петрографических методов изучения вещества нам удалось установить ранее никогда не отмечавшееся макроскопическое горно-породное явление - первичную кусковатость (агрегативность, скрытую текстуру, или фрустумацию) $)^{1}$, сначала для простых по минеральному составу и генезису, а затем и для полиминеральных и сложных по генезису макроскопически однородных и нетрещиноватых образцов горных пород [19-29, 56-58].

\section{Новое макроскопическое явление в горных породах}

В связи с тем что обнаруженное явление фрустумации горных пород располагается понятийно как бы в пограничье между «структурой» и «текстурой» (и ранее называлось нами элементарной ячейкой горных пород, надструктурной характеристикой, первичной кусковатостью, агрегативностью), стоит обсудить сами эти понятия. Анализируя вопрос о содержании понятий «структура» и «текстура» в геологии, мы насчитали 29 различающихся между собой определений этих терминов. «Структура агрегата характеризуется абсолютными и относительными размерами и формой индивидов, способом их сочетания, а также внешними особенностями отдельных минеральных зерен и агрегатов», «текстура горных пород - совокупность признаков строения горных пород, обусловленных относительным расположением и распределением составных частей породы», а «текстура руд - особенности строения рудной массы, обусловленные ориентировкой и пространственным соотношением различных минеральных агрегатов, слагающих руду» [6, с. 269-300]. Если логически следовать приведён- ным определениям, то широко используемое понятие «текстура массивная» представляет собой нелепость, поскольку подразумевает её отсутствие. А если к этому прибавить, что «Геологической словарь» даёт автономные ряды «структур» и «текстур» для трёх множеств с неясными границами (магматические и метаморфические породы; осадочные породы; руды), то становится понятной невозможность привести их в единую систему.

Обнаруживаемый нами (или визуализируемый с помощью различных физико-химических и минералого-петрографических методов) элемент строения горных пород должен занять промежуточное положение при их структурно-текстурной характеристике и применяться при детализации текстурного описания (как разные мозаичные узоры выполнения горно-породного пространства).

Для изучения фрустумации (первичной кусковатости горных пород) нами проведён комплекс разномасштабных исследований (от нано- до дециметрового уровня) наиболее простых по генезису горных пород с использованием традиционных минералого-петрографических методов (поляризационная микроскопия, фотолюминесценция, рентгенофазовый и микрорентгеноспектральный анализы), а также лазерной ультразвуковой эхоскопии, УЗИ-томографии и нейтронографии. Первичная кусковатость нами первоначально выявлена в мономинеральных горных породах различного генезиса при воздействии коротковолнового ультрафиолетового (УФ) излучения (длина волны $\lambda=254$ нм): хемогенно-осадочном крупнозернистом галите (Соликамское и Балтийское месторождения, Пермская и Калининградская области, Россия); метаморфогенном мелко-, среднезернистом статуарном доломит-кальцитовом мраморе (Каррарское месторождение, Тоскана, Италия), первично магматогенном гидротермально изменённом крупнозернистом силицитовом ядре пегматита (Калба, Казахстан); доломитовом мраморе Кибик-Кордонского месторождения (Красноярский край, Россия); метаморфогенном шокшинском (Карелия), уфалейском, кыштымском, тасеевском и егустинском кварцитах и миасском кварцитопесчанике (Урал, Россия); магматогенном среднезернистом кальцитовом безрудном карбонатите (Большетагнинское месторождение, Саян, Россия); обыкновенных и драгоценных опалах (включая искусственные) разного генезиса (из месторождений Либанка, Словакия; КуберПеди, Андамука, Лайтнинг Ридж, Квинсленд, Южная и Центральная Австралия; Воло и Мезезо, Эфиопия; Эрандике, Гондурас; Радужное, Северное Приморье; Липовка, Урал; Халилово, Башкирия, Россия; КараОба, Казахстан; Акари, Перу; Куэтеро, Мексика; ХартМаунтин, Орегон, и Йеллоустонский национальный парк, США). Позже она была выявлена при помощи тех же методов и в полиминеральных горных породах: среднезернистом амазонит-альбитовом редкометалльном граните, а также в крупнозернистом альбит-амазонитовом редкометалльном граните (Этыкинское танталовое месторождение, Забайкалье, Россия); первично магматогенном автометасоматически изменённом средне-, мелкозернистом щелочном редкометалльном гра-

${ }^{1}$ В отличие от феноменологически наблюдавшегося А. М. Садовским с сотрудниками явления дробления горных пород взрывом на дискретные гранулометрические фракции (и названного им «естественной кусковатостью» - блочностью), нами 6 неразрушенных горных породах визуализируется первичная кусковатость - скрытая текстура, существующая до разрушения, а возможно и регулирующая её развитие. Поэтому установленное явление предлагается называть фрустумацией - первичной кусковатостью (от латинского frustum - кусок). 
ните Зашихинского танталониобиевого месторождения (Восточная Сибирь, Россия); метасоматическом крупнозернистом датолитовом скарне Дальнегорского месторождения (Приморье, Россия); лейкократовом двуполевошпатовом граните Мансуровского месторождения (Башкирия); сером биотитовом граните Покостовского месторождения (Украина).

В общем случае, по нашим данным, границы фрустумов представляют собой субмикроскопической апертуры трещины (особенно ярко это нами визуализировано в благородных опалах как наилучшей модели наиболее простых по генезису мономинеральных супертонкозернистых равномернозернистых горных пород). В автометасоматически преобразованных амазонитальбитовых субщелочных редкометалльных гранитах Забайкалья и Казахстана (массивы Орловка, Этыка, Ачикан и Майкуль) по границам фрустумов развивается вторичный лейстовый альбит, разрастается «горошковидный» кварц и литиевые слюды, содержащие пластинчатый колумбит-танталит. В автометасоматически преобразованных щелочных редкометалльных гранитах Зашихинского месторождения (Восточная Сибирь, Россия) по этим границам развивается вторичный лейстовый альбит и торит с пирохлором, тогда как циркон распределён в породах равномерно и независимо от границ фрустумов.

При вращении образцов ни интенсивность люминесцентного свечения, ни границы первичных кусков (фрустумов) - закономерных ансамблей минеральных зёрен с различной интенсивностью люминесценции не изменялись. Механическая обработка (распиловка для приготовления шлифов алмазным инструментом и шлифовка абразивными порошками) также не влияла на положение границ фрустумов с различной интенсивностью люминесцентного свечения.

На дериватографах Q-1000 в ИГЕМ РАН (аналитик д. г.-м. н. Г. О. Пилоян) и STA-449 С Jupiter в МИСИС (аналитик д. г.-м. н. В. В. Коровушкин) в диапазоне температур 100-900 С исследованы дифференциально-тер-

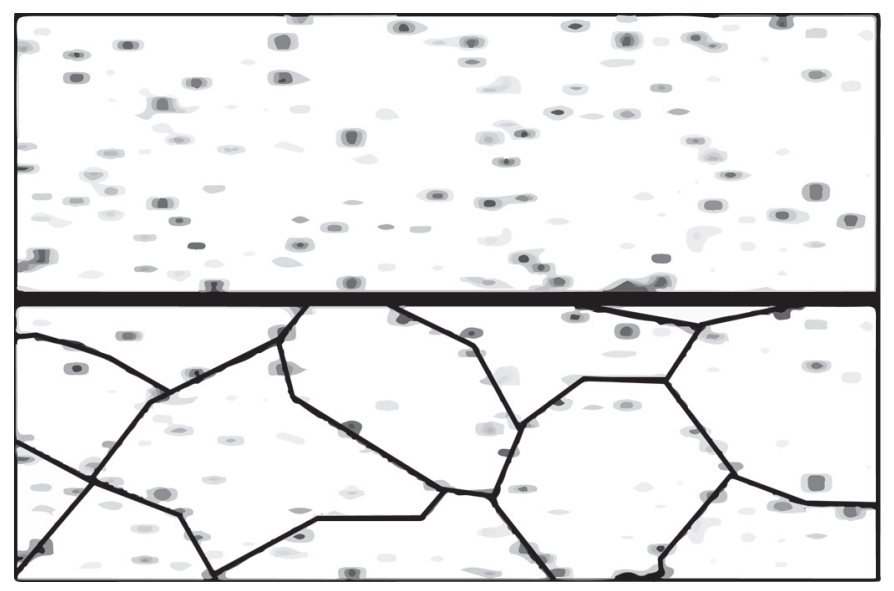

A мические характеристики фрустумов, составляющих изученный ранее в УФ-лучах образец кибик-кордонского доломитового мрамора. Наблюдались значимые отличия в потере веса вещества из фрустумов, люминесцировавших голубым и тёмно-фиолетовым цветом -43.3 и $45.1 \%$ соответственно.

Порошковые образцы этих же фрустумов, составляющих кибик-кордонский доломитовый мрамор, исследовались с помощью рентгенофазового анализа на дифрактометре ДРОН-3М (НПО «Буревестник», ЦКП МГУ) и RIGAKU (химфак МГУ, аналитик к. х. н. А. Г. Вересов) в режиме на отражение. При совмещении дифрактограмм вещества светло-голубого и тёмно-фиолетового фрустумов отмечена идентичность по положению основных отражений доломита (преобладающая фаза) и отличия их относительной интенсивности (наиболее явственные на дальних углах по 2ө).

С помощью метода лазерной ультразвуковой эхоскопии (ультразвуковой импульсный метод отражённых волн) на установке, смонтированной в Международном лазерном центре МГУ им. М. В. Ломоносова (НИИЯФ МГУ), просканировано 26 отшлифованных дециметрового размера внешне нетрещиноватых и однородных образцов горных пород плоскопараллельной формы. В качестве источника лазерных импульсов использовался импульсный твёрдотельный $\mathrm{Nd}$ :YAG-лазер. По акустическому треку, полученному от образцов в режиме эхоскопии, и значению их толщины с учётом плоскопараллельности вычислялись скорость распространения в них продольных упругих волн и глубина залегания дефектов, картина расположения которых в обработанном с помощью компьютерной программы виде выводилась на дисплей (рис. 1). Для всех исследованных образцов горных пород наблюдались разные картины неоднородного внутреннего строения, интерпретируемые как наличие агрегатов минеральных зёрен (первичных кусков, парагенезисов - фрустумов), разграниченных между собой системами микроскопической (по апертуре трещин, но вполне явственной) трещиноватости [27].

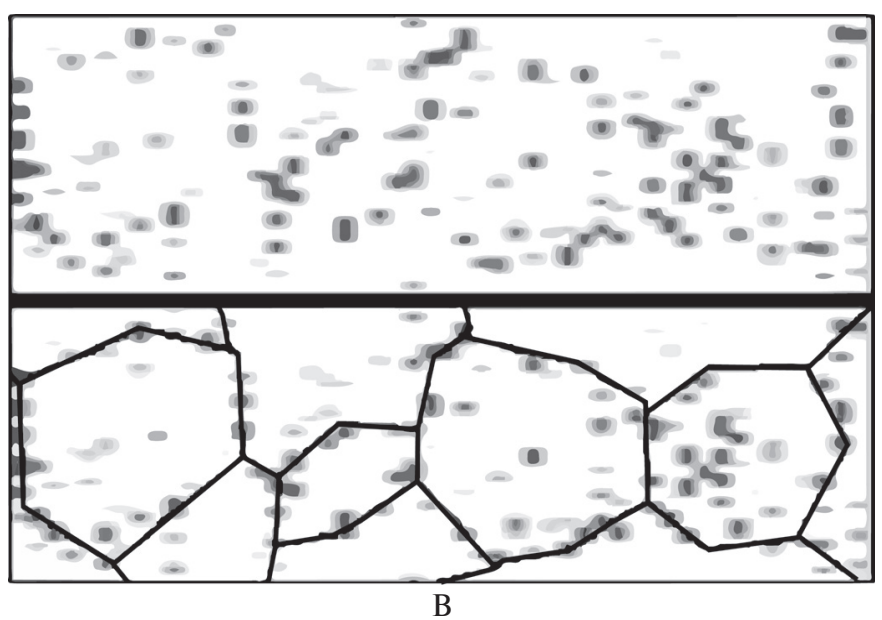

Рис. 1. Визуализированная методом лазерной ультразвуковой эхоскопии картина скрытой текстуры (фрустумации, или первичной кусковатости) мономинеральных горных пород: А - кибик-кордонского мелко-, среднезернистого кальцит-доломитового мрамора; В - кыштымского мелко-, среднезернистого гранулированного кварцита. Вертикальный размер образцов 13 и 12 мм соответственно. Аналитик С. А. Коваленко (МГГА), д. ф.-м. н. Е. Б. Черепецкая (НИИЯФ МГУ). Верхняя часть рисунка - исходная картина лазерной ультразвуковой эхоскопии образцов, нижняя - ретушированная

Fig. 1. Visualized with the help of laser ultrasonic echoscopy supertexture pattern of rocks inner composition (frustumation, or primary lumpiness): A - Kibik-Kordonsky medium-fine-grained calcite-dolomitic marble, B - Kyshtymsky medium-fine-grained granulated quartzite. Specimen width: 13 and $12 \mathrm{~mm}$, respectively. The upper part of the figure - original pattern of laser ultrasonic echoscopy of the samples, the lower one is retouched by us. Analysts S. A. Kovalenko (Moscow State Mining Academy) and E. B. Cherepetskaya (Doctor of Physical and Mathematical Sciences, SINP Moscow State University) 
Методом УЗИ-томографии (томографического просвечивания с применением дефектоскопа УД-У2Н ПМ, предназначенного для измерения скорости распространения продольных волн с постоянной скоростью 4000 м/с (лаборатория Ц-03 сейсмометрии и геоакустики геофизического отделения геологического факультета МГУ им. М. В. Ломоносова, аналитик д. г.-м. н. М. Л. Владов), исследовано внутреннее строение макроскопически однородного светло-серого мелко-, среднезернистого двуполевошпатового мусковитового гранита Мансуровского месторождения облицовочного камня (Башкирия) и макроскопически однородного серого среднезернистого двуполевошпатового биотитового гранита Покостовского месторождения (Украина). С помощью программы АКТАКОМ было обработано 625 акустических замеров (точки возбуждения и приёма располагались на противоположных сторонах образцов гранитов размерами $12 \times 13 \times 6$ см по равномерной сетке с квадратными ячейками со стороной 2 см) и визуализировано их фрустумационное строение [27] (рис. 2). Отметим, что размер выявленных фрустумов в гранитах (порядка 2.5-3 см) соизмерим с длиной излучаемой волны -4 см.

\section{Наблюдение фрустумации в равнозернистых горных породах}

Характерные размеры и форма фрустумов в этих исследованных горных породах существенно различаются. Наименьшие по числу их слагающих минеральных зёрен наблюдаются в мономинеральных горных породах: в датолитовом скарне из Дальнегорска, силицитовом кварцевом ядре пегматита Калбы, мозырьском галите, кибиккордонском и статуарном каррарском мраморе - около $20-50$ зёрен в сечении (площадь $1 \times 2$ cм²) $^{2}$ и около $70-150$ зёрен в объёме.

Фрустумы в кальцитовом карбонатите состоят из $50-70$ зёрен кальцита в срезе (площадь $2 \times 3 \mathrm{~cm}^{2}$ ) и около 200-300 зёрен в объёме. Самые крупные фрустумы зафиксированы в полиминеральных горных породах сложно-

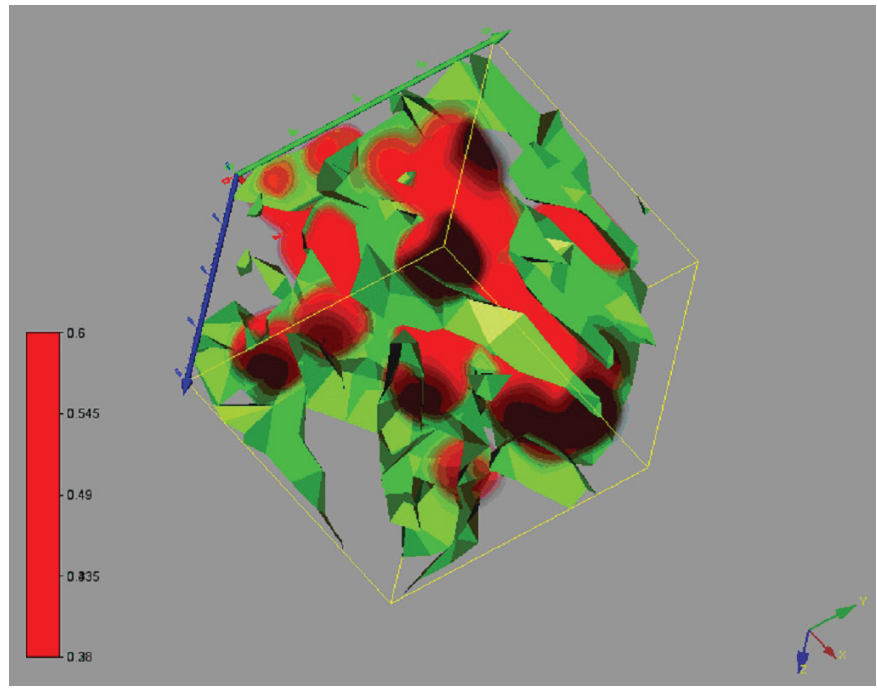

A го генезиса - этыкинском амазонит-альбитовом граните и тырныаузском липарите - и содержат более 1000 минеральных зёрен калиевого полевого шпата, кварца, альбита, слюды и акцессорных минералов. То же относится и к наблюдаемым без облучения жёстким ультрафиолетом фрустумам типа гексагональных ячеек в метасоматически изменённых амазонит-альбитовых редкометалльных гранитах Этыкинского и Ачиканского массивов (Забайкалье, Россия), а также образованиям спиралевидной формы

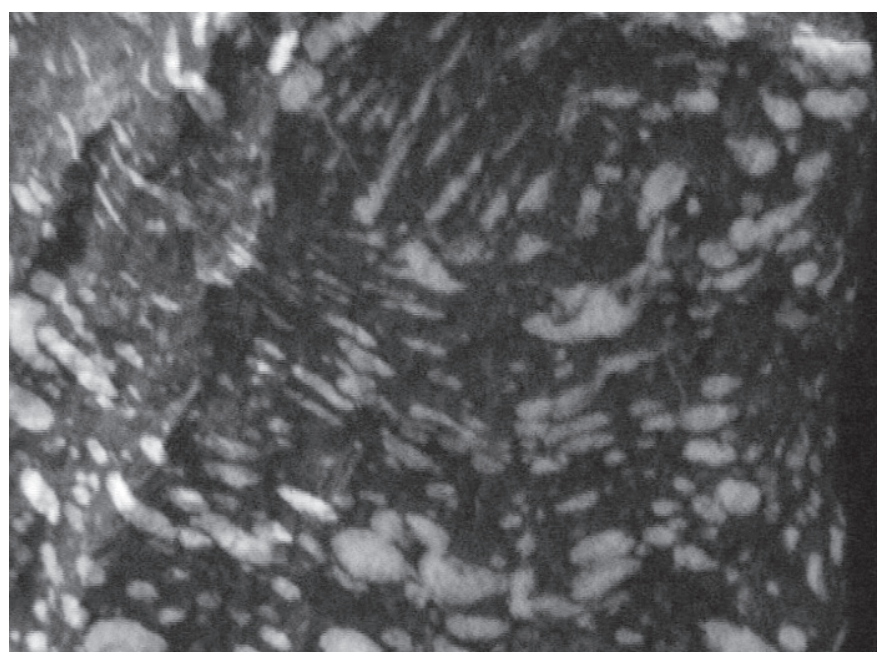

Рис. 3. Спиралевидная (вихревая) форма фрустума в щелочном овоидофире Ловозёрского щёлочно-ультраосновного массива (Кольский полуостров, Россия), подчёркиваемая распределением вытянутых таблитчатых кристаллов К-Naполевого шпата (светлое) в нефелине (тёмное). Диаметр фрустума около 18 см. Образец И.В. Буссен (1933 г.). Музей минералогии Института геологии Кольского отделения РАН, Апатиты. Дневное освещение. Фото М. Ю. Поваренных

Fig. 3. Spiral-like (vortical) frustum form in alkaline ovoidophire of the Lovozero alkaline-ultrabasic massif (Kola peninsula, Russia) revealed by the arrangement of elongated tabular crystals of $\mathrm{K}-\mathrm{Na}$ feldspar (light) in nepheline (dark). Frustum's diameter reaches $18 \mathrm{~cm}$. Specimen from I.V. Bussen (1933). Museum of Mineralogy of the Institute of Geology of the Kola Branch of the Russian Academy of Sciences, Apatity. Day light. Photo by M. Yur. Povarennykh

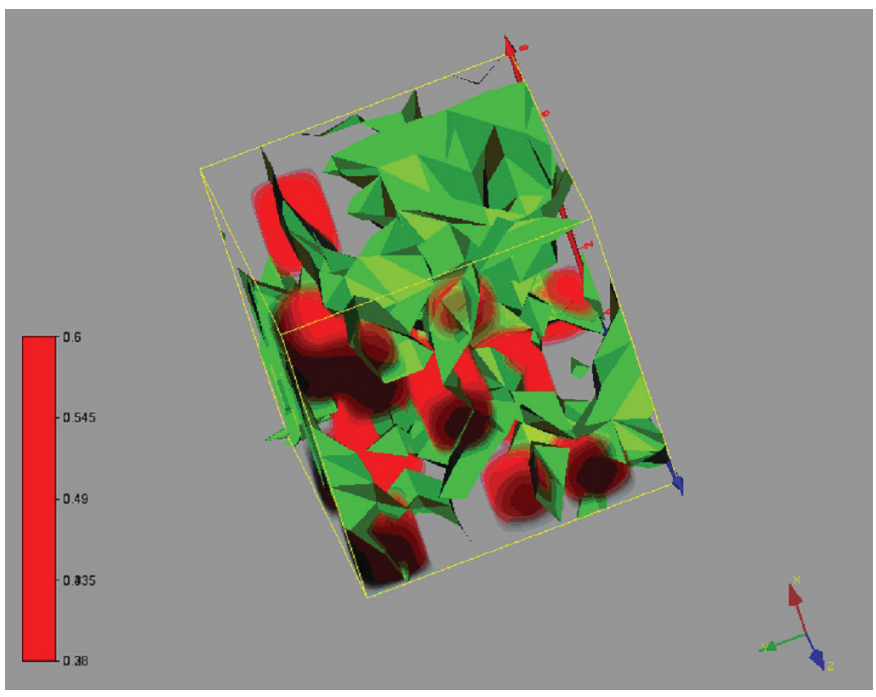

B

Рис. 2. Визуализация фрустумационного внутреннего строения светло-серого мелко-, среднезернистого гранита из Мансуровского месторождения облицовочного камня (Башкирия) с помощью УЗИ-томографии. Обработка 625 замеров. Кафедра сейсмометрии и геоакустики геофизического отделения геологического факультета МГУ (аналитик - д. г.-м. н. М. Л. Владов)

Fig. 2. Visualization with the help of ultrasound tomography of the frustumational inner fabric of light gray fine-medium-grained granite from the Mansurovsky deposit of facing stone (Bashkiria). Processing of 625 measurements. Department of Seismometry and Geoacoustics of the Geophysical Department of the Geological Faculty of Moscow State University (analyst - Doctor of Geological and Mineralogical Sciences M. L. Vladov). 
в метагранитах Украины (Капустинский и Корнинский массивы) и щелочным овоидофирам в нефелиновых сиенитах Ловозёрского массива (Россия) (рис. 3). В искусственных благородных опалах (БО) размер фрустумов, визуализированных с помощью длинноволнового УФизлучения и подтвержденных на РЭМ, варьировал в пределах 0.05-2.5 мм, а их форма была прихотливой в плане (рис. 4-5) и конусовидно-столбчатой в продольном сечении (рис. 6-9). Для образцов БО измерен средний диаметр фрустумов (под ними понимаются по-разному иризирующие фрагменты) и получена возможность вычислить плотность облекающей эти фрустумы системы первичной агрегативной субмикротрещиноватости. Всего изучено 16 образцов природных (12) и синтетических (4) БО.

По месторождению Лайтнинг Ридж (штат Новый Южный Уэльс, Австралия), где было исследовано 2 образца, характерные размеры составляющих их фрустумов в плоскости наблюдения в среднем оказались равны 2.0 мм. По месторождению Кубер-Педи (штат Южная Австралия) (3 образца) - характерные размеры фрустумов - 2.7 мм. По месторождению Харт-Маунтин (штат Орегон, США) (1 образец) - 2.5 мм. По месторождению

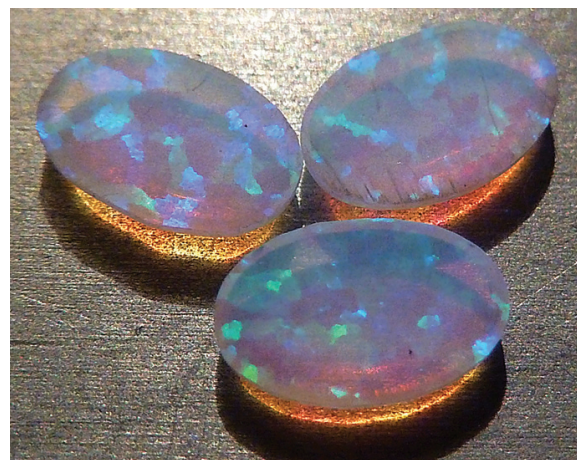

A

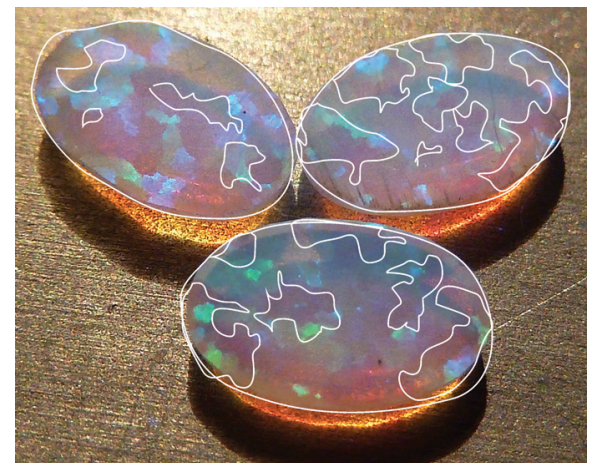

$\mathrm{A} 1$

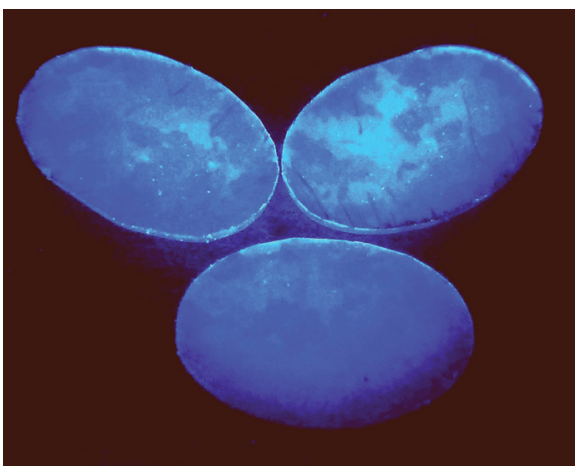

B

Рис. 4. Фрустумация в искусственном благородном опале (Япония): А - иризация в сине-зелёных тонах при естественном освещении; А1 - ретушированные границы фрустумов в УФ-излучении (белые контуры); В - фрустумы, выявленные в опалах при УФ-излучении. Обращает на себя ранее не отмеченное никем из исследователей такое свойство опалов, как взаимно однозначное соответствие между по-разному иризирующими участками (фрустумами) и участками, отличающимися по интенсивности фотолюминесценции. Длина образцов - 3 мм. Форма фрустумов в плане вестма прихотливая, их размеры варьируют от 0.3 до 1.3 мм, а их форма в поперечном сечении конусовидно-столбчатая. Фото предоставлено В. В. Морошкиным (ФГУП «ВИМС»)

Fig. 4. Frustumation in the cabochon sample of synthetic precious opal (Japan): A - irisation (play of coloures) in blue-green tones under natural illumination; A1 - retouched boundaries of different frustums in UV-irradiation (white contours); B - frustums revealed in opals in UV-irradiation. It should be noted that this phenomenon of one-to-one correspondence between the areas of different irisation (frustums) and areas differing in the intensity of photoluminescence has not been previously observed and marked by any researcher. Cabochon lengths is about $3 \mathrm{~mm}$. Frustum form is capricious in plane, their dimensions in plane vary from 0.3 to $1.3 \mathrm{~mm}$, and their form in cross-section is columnar. Photo by V. V. Moroshkin (VIMS)

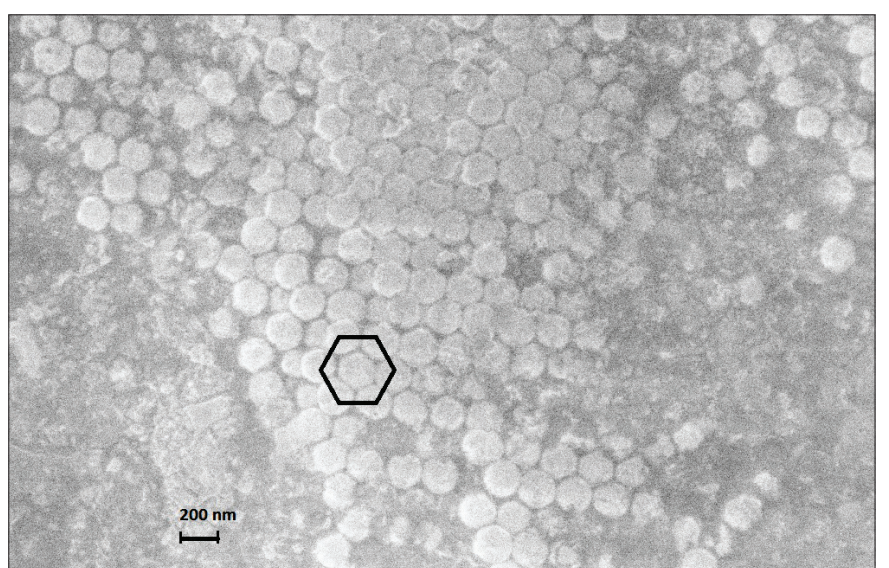

A

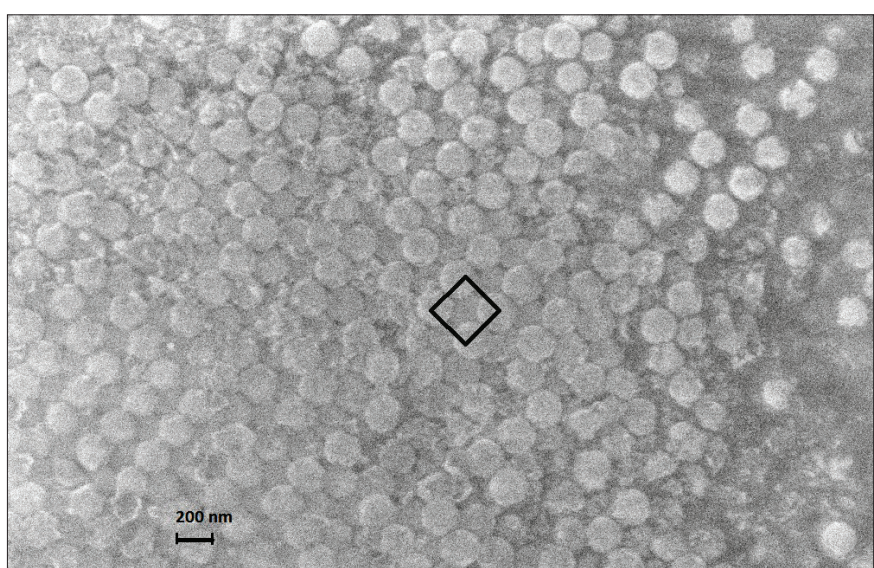

B

Рис. 5. Расположение глобул кремнезёма в разных фрустумах образца искусственного благородного опала, иризирующих синим и зелёным цветом: А - в «синем» фрустуме, В - в «зелёном» фрустуме. Размер глобул кремнезёма, располагающихся по «гексагональному» варианту квазиплотнейшей упаковки, составляет 242.5 нм. Расстояние между соседними интерстициями 221 нм (в оптическом диапазоне соответствует синему цвету иризации, $\lambda=440-485$ нм). Расположение глобул кремнезёма с явно заметным «квадратным» мотивом искаженной кубической плотнейшей упаковки. Размер глобул - 230 нм. Расстояние между соседними интерстициями около 248 нм (соответствует зелёному цвету иризации, $\lambda=495-565$ нм). Сканирующий электронный микроскоп LEO SUPRA 50VP. Фото д. х. Н. А. В. Кнотько (химический факультет МГУ)

Fig. 5. Difference in 3D-arrangement of silica globules from frustums with different irisation in blue and green colour tones: A - in blue frustum, B - in green frustum. Dimension of silica globules arranged in «hexagonal» variant of quasi-densest cubic package averages to $242.5 \mathrm{~nm}$. Distance between the nearest voids averages to $221 \mathrm{~nm}$ that corresponds in the optical range to the blue colour $(\lambda=440-$ $485 \mathrm{~nm}$ ). Dimension of silica globules arranged with a clearly noticeable «square» motif of distorted quasi-densest cubic package averages to $230 \mathrm{~nm}$. Distance between the adjacent voids averages to $248 \mathrm{~nm}$ that corresponds in the optical range to the green colour $(\lambda=495-$ $565 \mathrm{~nm}$ ). Sample of the synthetic precious opal. Scanning electron microscope LEO SUPRA 50VP. Photo by Doctor of Chemistry Science A. V. Knot ko (Chemical Faculty, Moscow State University) 

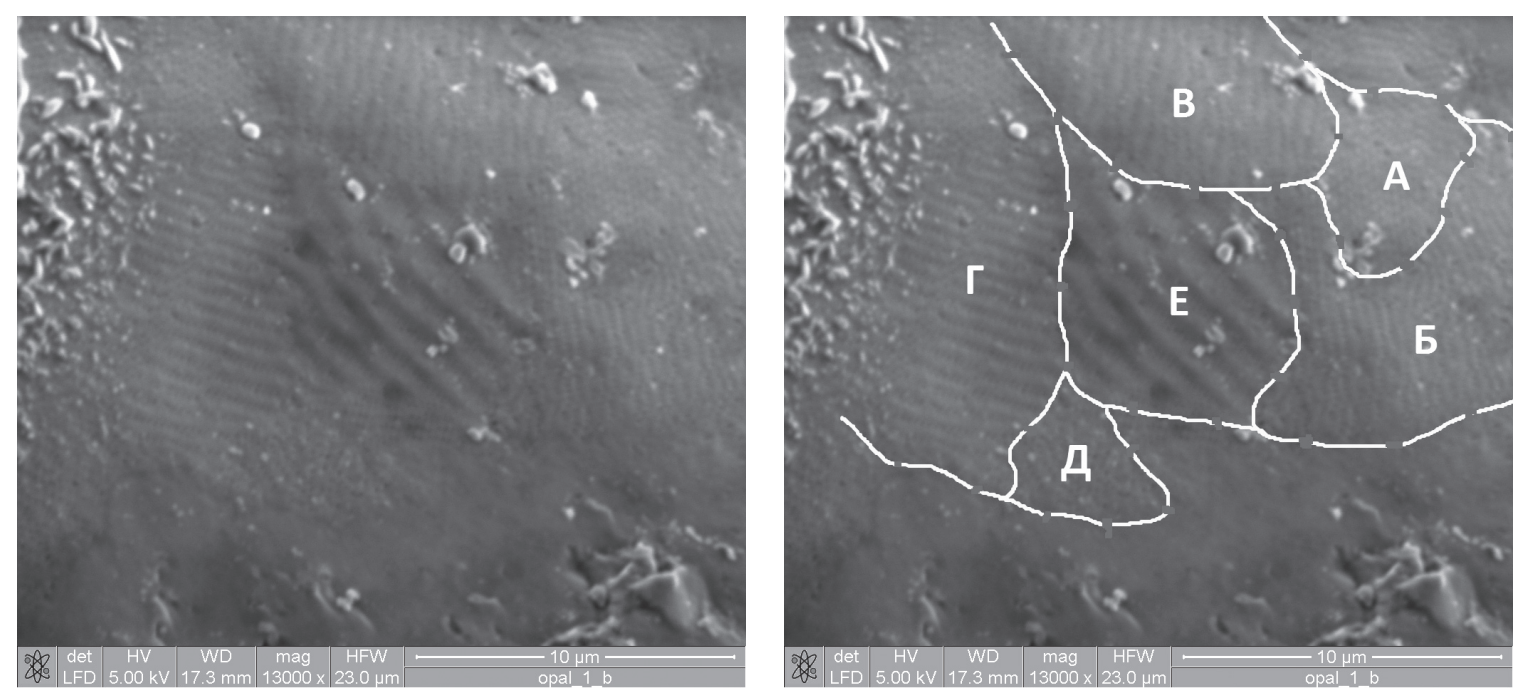

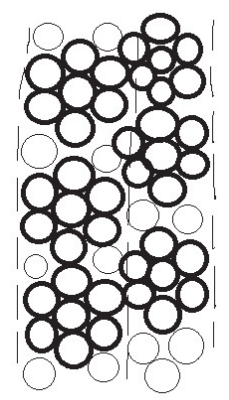

A

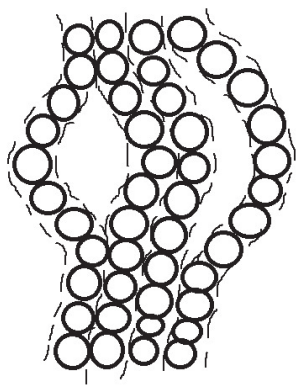

Б

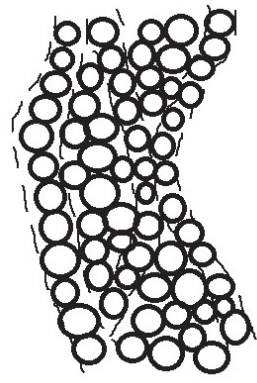

B

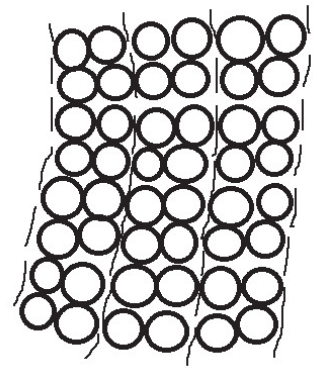

$\Gamma$

Рис. 6. Области разного фрустумационного строения в образце благородного опала (месторождение Андамука, Ю. Австралия). Границы областей (фрустумов) ретушированы белым пунктиром (А-Е). Фото во вторичных электронах. Сканирующий электронный микроскоп Quanta 200 3D FEI. Схемы строения разных первичных агрегатов глобул водного кремнезёма (минералоидов опала): А и Д - «гексагональная» КПУ, Б, В - искаженная КПУ («квадратная»), Г - «будины» КПУ, Е - удвоенная (по сравнению с фрустумом Г) искаженная КПУ

Fig. 6. Areas with different frustumational inner fabric in the sample of precious opal (Andamooka deposit, South Australia). The boundaries of the regions (frustums) are retouched with a white dotted line (A-E). Photo in secondary electrons. Scanning electron microscope Quanta 200 3D FEI. Schemes of the structure of different primary aggregates of globules of aqueous silica (opal mineraloids): A and Д «hexagonal» variant of quasi-densest cubic package (CP), Б, B - distorted quasi-densest CP («square»), $\Gamma$ - «boudines» $\mathrm{CP}, \mathrm{E}-\mathrm{doubled}$ (in comparison with $\Gamma$ scheme) $\mathrm{CP}$

в Словакии (гора Либанка, Червеница) (1 образец) 2.0 мм. По месторождению в Перу (Акари) (2 образца) 2.0 мм. По месторождению в Эфиопии (провинция Воло) (3 образца) - 1.5 мм. Для искусственных опалов разного типа (4 образца) характерные размеры составляющих их фрустумов - от 0.05 до 2.5 мм.

Одним из результатов исследования ряда образцов относительно простых по генезису и мономинеральных мелкозернистых горных пород - кварцитов, мраморов и обсидианов - с помощью метода SANS (малоуглового рассеяния нейтронов) в Объединённом институте ядерных исследований (ОИЯИ, Дубна, Россия, аналитики д. ф.-м. н. А. Н. Никитин и А. И. Куклин) явилось установление размерного порядка этой системы первичной агрегативной нанотрещиноватости (апертура трещин составила 50-100 нм, в среднем 60 нм), образующей ветвящуюся сеть по всему объёму изученных пород.

Изучение разномасштабной трещиноватости проводилось в образцах разных горных пород на малоугловом нейтронном спектрометре ЮМО-реактора ИБР-2. Обработка данных проводилась с помощью пакета программ SAS. Рассеяние нейтронов происходило на пористо-трещиноватых структурах внутри вещества изученных образцов горных пород. Онтогеническая интерпретация полученных с помощью метода SANS результатов следующая. Первое нарушение сплошности минераль- ного вещества горных пород - с апертурой субмикротрещиноватости 3-10 нм (в среднем 4 нм) - это контакты минеральных индивидов, растущих синхронно (так называемые индукционные поверхности совместного и одновременного роста $[7,30,31,38]$. Второе - с апертурой микротрещиноватости 50-100 нм (в среднем 60 нм) - это контакты между соприкоснувшимися в процессе разрастания закономерными первичными агрегатами минеральных зёрен - фрустумами [21-24, 26-29].

При изучении явления фрустумации в опалах мы рассматривали опалы как супертонкозернистые мономинеральные горные породы, состоящие из агрегата мельчайших минеральных индивидов субмикронного размера (150-450 нм) - глобул кремнезёма (рис. 5, 6). Исследование внутреннего строения опалов проводилось с помощью сканирующего электронного микроскопа SUPRA 50VP LEO (аналитик д. х. н. А.В. Кнотько) и сканирующего электронного микроскопа Quanta 200 3D FEI (аналитик к. г.-м. н. С. Ю. Янсон) (рис. 5, 6). В отличие от некоторых образцов искусственного БО, выращенных в спокойных автоклавных условиях, где отмечаются усечённо-столбчатые формы фрустумов (известные среди геммологов как digits - от английского «пальцы», или «знаки», назовем их 3D-фрустумы) (рис. 8, 9), внутреннее строение природных опалов чаще всего характеризуется слоистой толстотаблитчатой или пластинчатой 


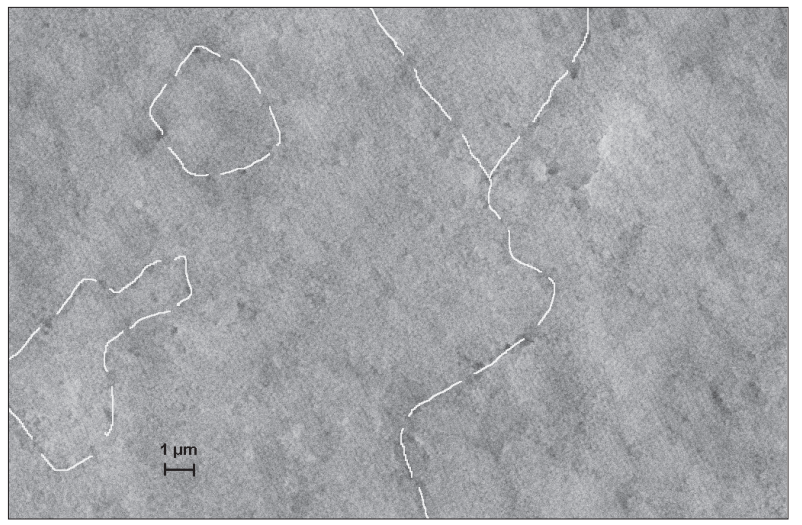

A

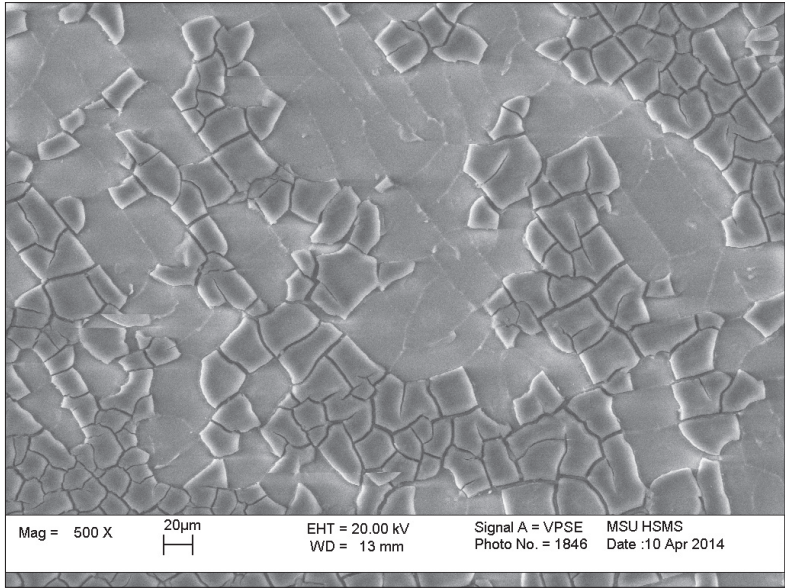

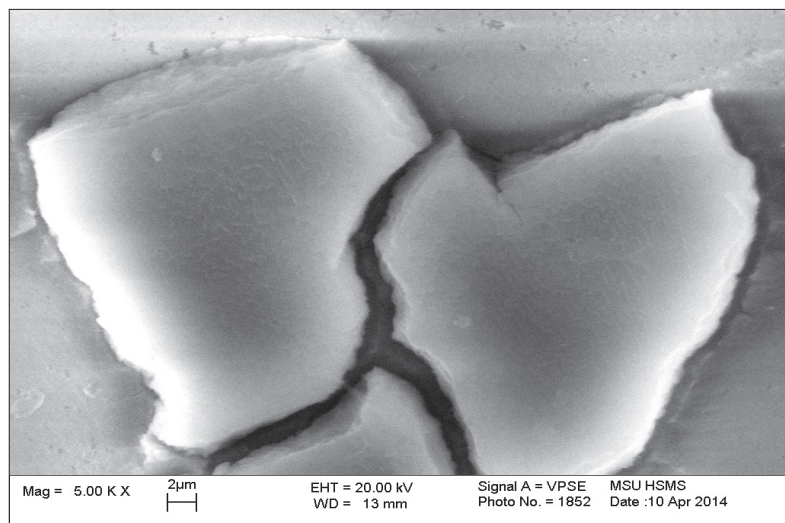

B

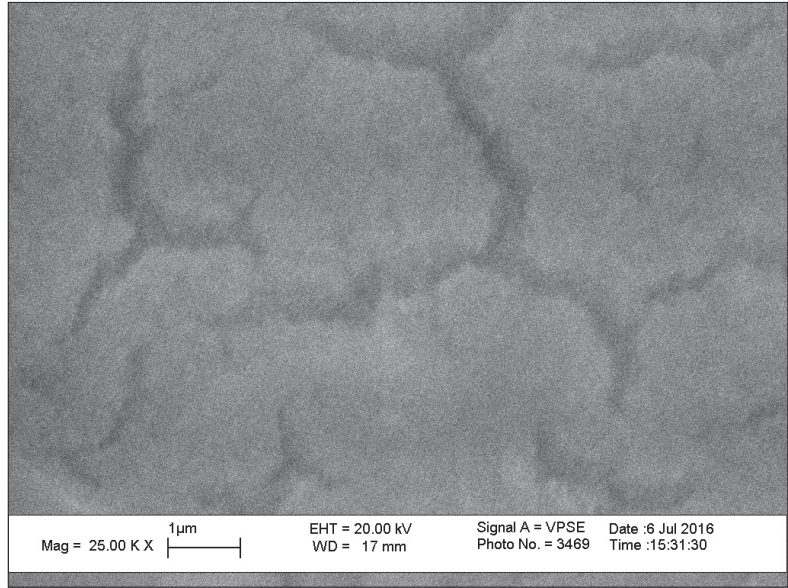

D

Рис. 7. Характер фрустумации (2D- и 3D-) в природных благородных и обыкновенных опалах (на снимке А границы фрустумов ретушированы): А — «белый» благородный опал из коры выветривания (Кубер-Педи, Ю. Австралия); В - благородный опал гидротермального генезиса (Гондурас); С - благородный «сэндстоун» опал из коры выветривания (Андамука, Ю. Австралия); $\mathrm{D}$ - «огненный» благородный опал гидротермального генезиса (Керетаро, Мексика)

Fig. 7. The character of frustumation (2-D and 3-D) in natural precious and common opals (in picture A, the boundaries of the frustums are retouched): A - «white» precious opal from the weathering crust of Coober Pedy, South Australia); B - precious opal of hydrothermal genesis (Honduras); C - precious «sandstone» opal from the weathering crust of Andamooka, South Australia); D - «fire» precious opal of hydrothermal genesis (Queretaro, Mexico)

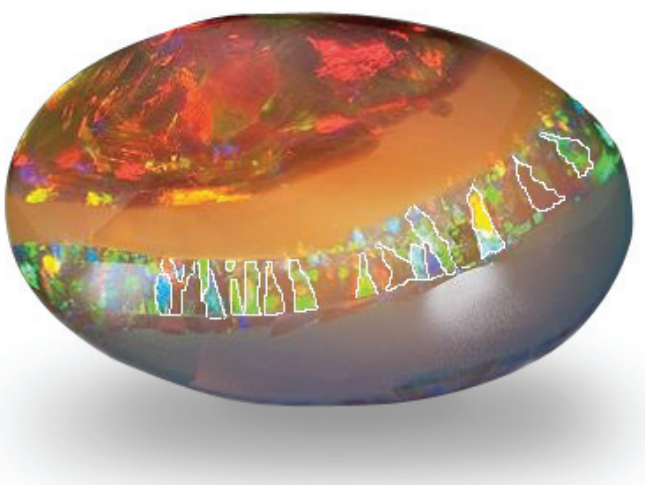

A

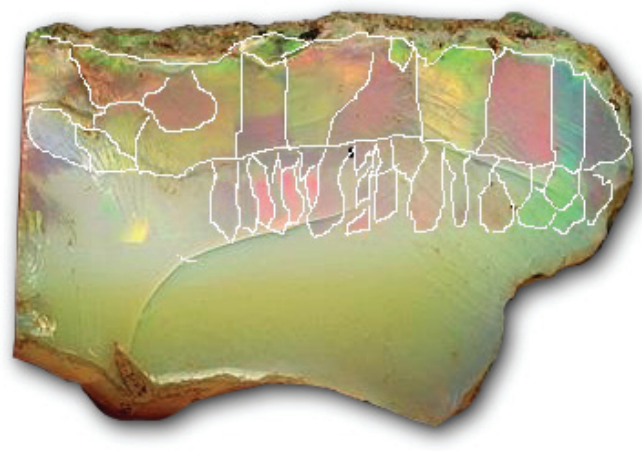

B

Рис 8. А - кабошон благородного опала, крупный, овальной формы. В - зональный кабошон, в строении которого проявлены почти все разновидности опалов, присутствующих на месторождении: от коричневато-оранжевого до «белого», от прозрачного до мутного просвечивающего, от обыкновенного до благородного. Эта зональность, по-видимому, вызвана последовательным отложением горизонтально ориентированных слоёв опала в полости. В слое «белого» опала с сильной иризацией визуализирована параллельно-столбчатая фрустумация, которую авторы статьи называют digit pattern. Подчеркнём, что зональность перпендикулярна столбчатости, что означает: фрустумы развивались вертикально. Месторождение Вегел Тена (провинция Волло, Эфиопия). Фото R. Weldon (Rondeau et al., 2010). Границы фрустумов в опале ретушированы нами

Fig. 8. A - large oval cabochon of noble opal. B - in the structure of this zonal cabochon, almost all the varieties of opals, present in the deposit, are exhibited: from brownish-orange to «white», from transparent to cloudy translucent, from ordinary to precious. This zoning, apparently, is caused by the sequential deposition of horizontally oriented layers of opal in the cavity. In the layer of «white» opal with strong irisation, the parallel-columnar frustumation is visualized, which is termed as digit pattern by the authors of the paper. We emphasize that the zonality is perpendicular to the columnar, which means: the frustums developed vertically. The Vegel Tena deposit (Wollo province, Ethiopia). Photo R. Weldon (Rondeau et al., 2010). The borders of the frustum in opal are retouched by us 


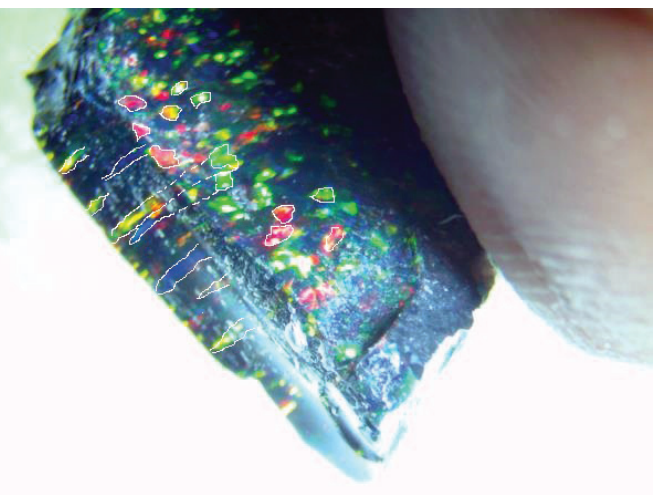

A

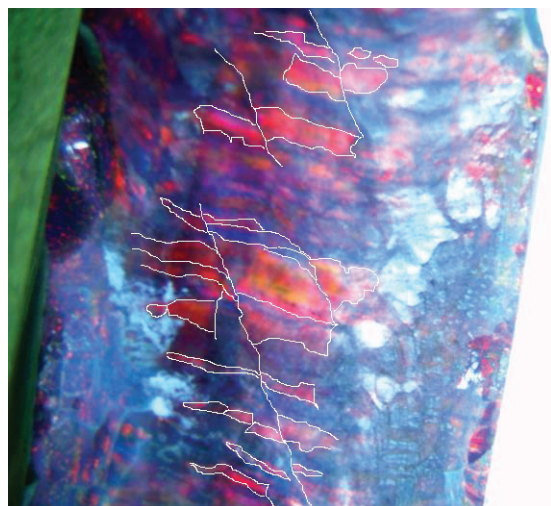

B

Рис. 9. Образцы искусственного благородного опала (ZrO2-керамика, Дубна, Россия). Предоставлены В. И. Масаловым (ФТТ РАН, Черноголовка): А - границы некоторых фрустумов в образце ретушированы нами; В - проявлена наложенная трещинная тектоника и смещение фрустумов опала по нарушениям

Fig. 9. Samples of synthetic precious opal $\left(\mathrm{ZrO}_{2}\right.$-ceramics, Dubna, Russia). Provided by V. I. Masalov (PTT RAS, Chernogolovka). The boundaries of some frustums in the sample are retouched by us. B. Overlapping fractured tectonics and displacements of opal frustums on fractures is revealed

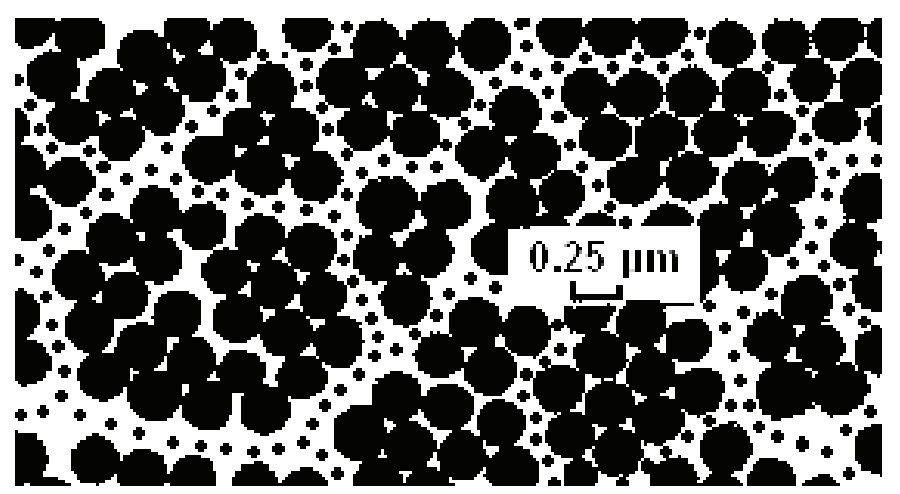

A

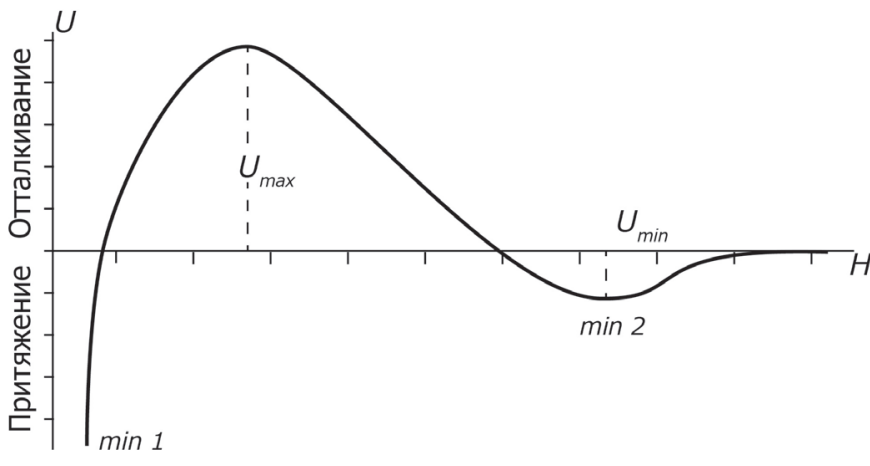

Б

Рис. 10. А - образование фрустумов в синтетическом геле кремнезёма из сильно заряженных сферических глобулей коллоидного размера [35]. Пунктиром выделен один из фрустумов. Б - теоретическая потенциальная кривая энергии (U) взаимодействия глобулей кремнезёма [36]

Fig. 10. A - formation of frustums in synthetic silica gel from highly charged spherical globules of colloidal size [35]. We dotted one of the frustums. Б - theoretical potential energy (U) curve of the interaction of silica globules [36]

текстурой (2D-фрустумы) (рис. 7). Опалы из месторождения провинции Воло (Эфиопия) являются, по-видимому, исключением из этого правила: здесь широко развиты 3D-фрустумы (рис. 7, 8) [39, 40, 42-51, 53, 54, 57-65].

\section{О природе фрустумации}

\section{(скрытой текстуры горных пород)}

Морфология фрустумов и способ выполнения ими горнопородных тел, судя по исследованным образцам, весьма прихотливая, и для её описания, вероятно, придётся применять теорию фракталов. Объяснение явления фрустумации возможно, по нашему мнению, лишь при использовании синергетического подхода в науке о горных породах, в отличие от представления о горной породе как о простом наборе контактирующих друг с другом минеральных зёрен. Тогда порода может быть представлена как результат возникновения первичных парагенетических ансамблей (фрустумов) минеральных зёрен и их кооперативного поведения (часто имеющего неявно вихревой характер с аттрактором, располагающимся по направлению градиента диссипации энергии - температурному, как в ячейках Бенара).

Рассмотрение фрустумации горных пород как их синергетического свойства [24, 26-28], по сути, может способствовать включению теории Д. С. Коржинского в более общую теорию диссипативных структур Ильи Пригожина и теорию диссипативной саморепликации Джереми Ингланда. Фрустумация горных пород, возможно, является макроскопической визуализацией так называемого мозаичного равновесия в них и даёт представление не только о нижнем размерном пределе этих отдельных элементов «мозаики», но и о форме и характере границ этих своеобразных горно-породных фаз. Для объяснения явления фрустумации в БО (визуализируемого мозаичным узором иризации) предлагается теория ДЛФО (Дерягин - Ландау - Фервеи - Овербек) [41, 66] для сильно заряженных частиц коллоидного размера и её расширение Ильей Романовичем Пригожиным [55] и Джереми Ингландом [52].

На рис. 10, А видно, что размеры фрустумов в искусственном геле кремнезёма соответствуют расстоянию между 1-м и 2-м барьерами притяжения на рис. 10, В, но они меньше, чем фрустумы в БО (рис. 4-5). По данным $[10,15,36]$, это может быть связано с уменьшением потенциального барьера отталкивания глобул кремнезема из-за увеличения ионной силы минералообразующего раствора. Вариации в размерах и форме фрустумов зависят, по-видимому, от условий консервации и созревания геля кремнезёма (периоды без сильных землетрясений и локальных перепадов давления).

Исследования выполнены на оборудовании ресурсного иентра Научного парка СПбГУ «Ресурсный иентр микроскопии и микроанализа». 


\section{Литература}

1. Бескин С. М., Ларин В. Н., Марин Ю. Б. Редкометалльные гранитовые формации. Л.: Недра, 1979. 280 с.

2. Бродская Р. Л., Марин Ю. Б. Использование стереометрических методов в онтогеническом анализе горных пород // ЗВМО. 1979. Вып. 2. Ч. 108. С. 141-153.

3. Бродская Р. Л., Виноградов Е. А., Голованов В. И., Ирисова Н. А., Черепанов В. А. Обнаружение пространственной периодичности в структуре горных пород методами дифракции и радиовидения // Препринт-19. Ин-т Общей физики. АН СССР. М. 1991.7 с.

4. Васильев В. И., Драгунов В. И., Рундквист Д. В. «Парагенезис минералов» И «формация» в ряду образований различных уровней организации // ЗВМО. 1972. Ч. СІ. Вып. 3. С. 281-289.

5. Высоцкий С. В., Курявый В. Г., Карабцов А. А. Наноструктура благородного опала месторождения Радужное (Сев. Приморье, Россия) // ДАН. 2008. Т. 420. № 4. С. 516-519.

6. Геологический словарь: В 2 т. М.: Недра, 1973. 943 с.

7. Григорьев Д. П., Жабин А. Г. Онтогения минералов (индивиды). М.:Наука, 1975. 340 с.

8. Делицин И. С. Структурообразование кварцевых пород. М.: Наука, 1985. 191 с.

9. Делицин И. С. Элементарная ячейка горных пород и механизм их самоорганизации // Идея развития в геологии: вещественный и структурный аспекты. Новосибирск, 1990. C. $273-280$.

10. Денискина Н. Д., Калинин Д. В., Казанцева Л. К. Благородные опалы (природные и синтетические). Новосибирск: Наука, 1987. 173 с.

11. Евзикова Н. 3. Общие принципы структурной организации геологических тел // Фундаментальные проблемы естествознания: Тр. конгресса. 2000. Т. II. СПб. С. 24-38.

12. Жабин А. Г. Синнезис и дифференциация течения в магматических расплавах // ЗВМО. 1971. Ч. 100. № 5. С. 578-589.

13. Жабин А. Г. Диагностика синхронности продуктов минералообразования // Минералогический журнал. 1979. T. 1. № 1. С. 42-56.

14. Жабин А. Г., Юшкин Н. П. Синтез и квантование пространства-времени в процессах природного минералообразования // ДАН. 1991. Т. 318. № 1. С. 164-168.

15. Калинин Н. С., Сердобинцева В. В. Генезис и поисковые критерии месторождений благородного опала // Геология и геофизика. 2003. Т. 44. № 4. С. 340-347.

16. Коржинский Д. С. О равновесии при процессах минералообразования // Известия АН СССР. Сер. Геол. 1965. № 2. C. $128-131$.

17. Левинсон-Лессинг Ф. Ю., Жемчужный С. Ф. Порфировидное строение и эвтектика // Зап. СПб. мин. об-ва. 2 сер. 1906. Ч. 44. Вып. 1. С. 244-256.

18. Никитин А. Н. Образование пьезоэлектрических текстур в кварцсодержащих горных породах // Физ. Земли. 1996. № 10. C. $15-21$.

19. Поваренных М. Ю. О пространственной регулярности («элементарной ячейке») горных пород // Биохимические карбонаты антропогеновых озер и источников: Труды конф. Пермь, 1989. С. 138-151.

20. Поваренных М. Ю. К созданию естественной классификации горных пород на основе теоретико-системной концепции «элементарных ячеек» // Система «Планета Земля»: VIII научн. семинар. М.: РОО «Гармония строения Земли и планет». 2000. С. 73-83.

21. Поваренных М. Ю. О фрустумации (свойстве первичной кусковатости, фрагментации) горных пород и её влиянии на их дробимость и возможность крупнокусково- го обогащения. // Тр. Годичного собрания РМО. СПб., 2006. C. $168-176$.

22. Поваренных М. Ю. Об установлении нового свойства горных пород - скрытой текстуры // Доклады РАН. 2008. T. 419. № 2. С. 233-236.

23. Поваренных М. Ю., Бескин С. М. Применение современных технических и аналитических средств выявления первичной кусковатости (фрустумации или образования «элементарной ячейки») горных пород // Тр. I Всероссийского семинара по технологической минералогии. Петрозаводск, 2006. C. $138-145$.

24. Поваренных М. Ю., Жабин А. Г. Фрустумация (первичная кусковатость) горных пород как проявление квантования - зернистости горно-породного уровня простремени // Уральский геол. журнал. 2007. № 5 (59). С. 51-60.

25. Поваренных М. Ю., Загубный Д. Г., Корчуганова. Н. И. Поиски благородного опала в Южной Австралии с использованием дистанционных методов // Разв. и охрана недр. 2014. № 7. C. 31-40.

26. Поваренных М. Ю., Кнотько А. В., Матвиенко Е. Н., Бурмистров А. А., Плечов П. Ю., Лукша В. Л. Особенности иризации в благородных опалах в свете их мозаично-кластерного (фрустумационного) внутреннего строения // Доклады PAH. 2016. T. 467. № 6. C. 701-703.

27. Поваренных М. Ю., Матвиенко Е. Н. Развитие теории минералогии и петрографии. Теоретико-системное обоснование естественной классификации горных пород и построения периодической системы минералов. Саарбрюккен: Издво LAP Lambert, 2014. $117 \mathrm{c}$.

28. Поваренных М. Ю., Матвиенко Е. Н. Новое макроскопическое свойство горных пород - фрустумация - как проявление квантования-зернистости горно-породного уровня простремени // Пространство и время. 2015. № 3. С. 327-338.

29. Поваренных М. Ю., Рассулов В. А., Матвиенко Е. Н. О скрытой текстуре (фрустумации) наиболее простых по минеральному составу и генезису горных пород // Мінерал. журн. (Ukraine). 2014. Т. 36. № 1. С. 88-100.

30. Попов В. А. Практическая кристалломорфология минералов. Свердловск: УНЦ АН СССР, 1984. $191 \mathrm{c.}$

31. Попов В. А. Практическая генетическая минералогия. Екатеринбург: УрО РАН, 2011. 167 с.

32. Садовский М. А. Естественная кусковатость горной породы // ДАН СССР. 1979. Т. 247. Вып. 4. С. 829-831.

33. Садовский М. А. О распределении размеров твердых отдельностей // ДАН СССР. 1983. Т. 269. № 1. С. 69-72.

34. Садовский М. А., Болховитинов Л. Г., Писаренко В. Ф. О свойствах дискретности горных пород // Препринт ИФЗ АН СССР. 1981. Вып. 1. С. 15-28.

35. Самойлович Л. А., Балакирев В. Г. и Самойлович С. М. Некоторые особенности микроструктуры синтетического и природного благородного А-опала // Разведка и охрана недр. 1995. № 3. С. 23-27.

36. Сердобинцева В. В., Калинин Д. В. и Восель С. В. Формы коллоидного кремнезёма, участвующие в образовании благородного опала, и механизм окремнения его гелевых кристаллов // Геология и геофизика. 1999. Т. 31. № 8. С. 1116-1120.

37. Суставов O. А. Структуры кристаллизации кварца в жильных полостях // Уральская минералогическая школа 2005. Екатеринбург: Изд-во УГГУ, 2005. 93 с.

38. Ферсман A. Е. Элементы разграничения двух одновременно кристаллизующихся веществ. Доклады АН СССР. Сер. А. 1922. Декабрь-январь.

39. Choudhary G. Gem News International: An interesting opal. Gems \& Gemology. 2008. Vol. 44, No. 2. P. 172-174. 
40. Darragh P. J., Gaskin A. I., Terrel B. C., Sanders J. V. Origin of precious opal // Nature. 1966. V. 204. № 5018. P. 13-16.

41. Derjiagin B. V. \& Landau L. D. Theory of stability of strongly charged lyophobic sols // Acta Physicochim. USSR. 1941. V. 14. P. 633-662.

42. Flörke O.W., Gaetsch H., Martn B., Roller K. and Wirth R. Nomenclature of micro- and non-crystalline silica minerals, based on structure and microstructure // N. Jahr. fur Min.-Abh. 1991. 163. P. 19-42.

43. Fritsch E., Rondeau B. Gem News International: Rare optical phenomenon in play-of-color opal // Gems \& Gemology. 2009. Vol. 45, No. 2. P. 147-148.

44. Fritsch E., Rondeau B., Ostroumov M., Lasnier B., Marie A.-M., Barreau A., Wery J., Connouй J., Lefrant $S$. Découvertes récentes sur l'opale // Rev. de Gemmologie a.f.g. 1999. No. 138/139. P. 34-40.

45. Fritsch E., Gaillou E. Ostroumov M., Rondeau B., Devouard B. and Barreau A. Relationship between nanostructure and optical absorption in fibrous pink opals from Mexico and Peru // Eur. Jour. Miner. 2004. 16. P. 743-752.

46. Gaillou E. Relation entre Nanostructure, PropriétésPhysiques et Mode de Formation des Opales A et CT / PhD thesis, University of Nantes. 2006. 278 p.

47. Gaillou E., Delaunay A., Rondeau B., Bouhnik-le Coz M., Fritsch E., Cornen G., Monnier C. The geochemistry of opals as evidence of their origin // Ore Geology Reviews. 2008a. Vol. 34 P. 113-126.

48. Gaillou E., Fritsch E., Rondeau B., Aguilar-Reyes B., Barreau A., Ostroumov M., Post J. Common gem opal: An investigation of micro- to nano-structure // Am. Miner. 2008b. Vol. 93. P. 1865-1873.

49. Gauthier J.-P., Mazzero F., Mandaba Y., Fritsch E. L'opale d'Ethiopie: Gemmologie ordinaire et caractŭristiques exceptionnelles // Revue de Gemmologie a.f.g. 2004. No. 149. P. 15-23.

50. Gregor M. Opal mineralization of western Carpathians: mineralogy and petrogenesis. Comenius Univ. Bratislava. Fac. Nat. Sc. Geol. Inst. Advisor: doc. RNDr. Pavel Uher, PHd. 2011. 178 p.

51. Jones J. D., Segnit E. R. The occurrence and formation of opal at Coober Pedy and Andamooka// Australian Journal Sci. 1996. V. 29. № 5. P. 129-133.

52. England J. L. Statistical physics of self-replication // J. Chem. Phys. 139, 121923 (2013); doi: 10.1063/1.4818538.

53. Koivula J. I., Kammerling R. C., Fritsch E., Eds. Gem News: Opal from Ethiopia. Gems \& Gemology. 1994. Vol. 30, No. 1. P. 52-53.

54. Mazzero F., Gauthier J.-P., Rondeau B., Fritsch E., Bekele E. Nouveau gisement d'opales d'Ethiopie dans la Province du Welo: Preminres informations // Revue de Gemmologie a. f. g. 2009. No. 167. P. 4-5.

55. Nicolis G., Prigogine I. Self-Organization in Non-Equilibrium Systems: From Dissipative Structures to Order Through Fluctuations. New York: J. Willey \& Sons. 1977. 347 p.

56. Povarennykh M. Yu., Rassulov V. S., Lobzova R. V. Frustumation (fragmentation, lumpiness, «rock unit cells» formation) the first discovery of the rock universal property. Proc. XI Int. Cong. Mathem. Geol. «Quantitative Geology from Multiple Sources». Liege. 2006. CD-ROM D/2006/0480/31.

57. Povarennykh M. Yur., Matvienko E. N. Opals: Australian vs African // Russian Diamonds \& Jewelry. Autumn. 2015. P. 12-16.

58. Povarennykh M. Yur., Matvienko E. N. Description of precious opals diversity from S. Australia (Coober Pedy deposit) as superfine-grained rocks according to their different frustumational inner fabric // Proc. Int. Conf. Sofia. 2015. P. 173-184.

59. Reusch E. Ueber einen Hydrophan von Czerwenitza // Annalen der Physik. 1865. Vol. 200, No. 3. P. 431-448.
60. Rey P. F. Opalisation of the Great Artesian Basin (central Australia): an Australian story with a Martian twist // Australian Journ. Earth Sc. 2013. 60. P. 291-314.

61. Rondeau B., Mazzero F., Bekele E., Gauthier J.-P., Fritsch E. Gem News International: New play-of-color opal from Welo, Ethiopia. Gems \& Gemology. 2009. Vol. 45, No. 1. P. 59-60.

62. Rondeau B., Fritsch E., Mazzero F., Gauthier J.-P., CenkiTok B., Bekele E., and Gaillou E. Play-of-color opal from Wegel Tena, Wollo Province, Ethiopia // Gems \& Gemology. 2010. Vol. 46. No. 2. P. $90-105$.

63. Sanders J. V. Colour of Precious Opal // Nature. 1964. N. 204. P. 1151-1153.

64. Smith K. L. Opals from Opal Butte, Oregon. Gems \& Gemology. 1988. Vol. 24, No. 4. P. 229-236.

65. Spencer R. J., Levinson A. A., Koivula J. I. Opal from Querŭtaro, Mexico: Fluid inclusions study. Gems \& Gemology. 1992. Vol. 28, No. 1. P. 28-34.

66. Verwey F. I. W. \& Overbeek J. Th. Theory of stability of lyophobic colloids. Amsterdam. 1948. 287 p.

\section{References}

1. Beskin S. M., Larin V. N., Marin Yu. B. Redkometallnye granitovye formatsii (Rare metal granite formations). Leningrad: Nedra, 1979, 280 pp.

2. Brodskaya R. L., Marin Yu. B. Ispolzovaniestereometricheskih metodov $v$ ontogenicheskom analize gornyh porod (Application of stereometrical methods for ontogenetic analysis of rocks). ZVMO, 1979, No. 2, part 108, pp. 141-153.

3. Brodskaya R. L., Vinogradov E. A., Golovanov V. I., Irisova N. A., Cherepanov V. A. Obnaruzhenie prostranstvennoi periodichnosti $v$ strukture gornyh porod metodami difraktsii $i$ radiovideniya (Discovery of spatial periodicity in rocks structure by diffraction and radiovision). Preprint 19. Institute of general physics. USSRAS, Moscow, 1991. 7 pp.

4. Vasil'ev V. I., Dragunov V. I., Rundkvist D. V. «Paragenezis mineralov» $i$ «formatsiya» $v$ ryadu obrazovanii razlichny urovnei organizatsii (paragenesis of minerals and formation in series of formations of different levels of organization). ZVMO, 1972, No. 3, pp. 281-289.

5. Vysotskii S. V., Kuryavyi V. G., Karabtsov A. A. Nanostruktura blagorodnogo opala mestorozhdeniya Raduzhnoe (Sev. Primor'e, Rossiya) (Nanostructure of noble opal of Raduzhnoe deposit (Northern Primorye). RAS, 2008, V. 420, No. 4, pp. 516-519.

6. Geologicheskii slovar (Geological dictionary). Moscow: Nedra, 1973, 943 pp.

7. Grigorev D. P., Zhabin A. G. Ontogeniya mineralov (individy) (Mineral ontogenesis (individuals)). Moscow: Nauka, 1975, $340 \mathrm{pp}$.

8. Delitsin I. S. Strukturoobrazovanie kvartsevyh porod (Structural formation of quartz rocks). Moscow: Nauka,1985, $191 \mathrm{pp}$.

9. Delitsin I. S. Elementarnaya yacheika gornyh porod $i$ mehanizm ih samoorganizatsii (Elementary cell of rocks and mechanism of their self-organization). Ideya razvitiya $v$ geologii: Veschestvennyi i strukturnyi aspekty (Idea of development in geology: material and structureal aspects). Novosibirsk, 1990, pp. 273-280.

10. Deniskina N. D., Kalinin D. V., Kazantseva L. K. Blagorodnye opaly (prirodnye i sinteticheskie) (Noble opals (natural and synthetical)). Novosibirsk: Nauka, 1987, 173 pp.

11. Evzikova N. Z. Obschie printsipy strukturnoi organizatsii geologicheskih tel (General principles of structural organization of geological bodies). Proceedings of conference «Fundamentalnye problemy estestvoznaniya». V. II, 2000, St. Petersburg, pp. 24-38.

12. Zhabin A. G. Sinnezis $i$ differentsiatsiya techeniya $v$ magmaticheskih rasplavah (Synnesis and differentiation of flow in magmatic melts). ZVMO, 1971, part 100, No. 5, pp. 578-589. 
13. Zhabin A. G. Diagnostika sinhronnosti produktov mineraloobrazovaniya (Diagnostics of synchronicity of mineral formation products). Mineralogicheskii zhurnal, 1979, V. 1, No. 1, pp. 42-56.

14. Zhabin A. G., Yushkin N. P. Sintez $i$ kvantovanie prostranstva-vremeni $v$ protsessah prirodnogo mineraloobrazovaniya (Synthesis and quantification of space-time in natural mineral formation). RAS, 1991, V. 318, No. 1, pp. 164-168.

15. Kalinin N. S., Serdobintseva V. V. Genezis i poiskovye kriterii mestorozhdenii blagorodnogo opala (Genesis and search criteria of noble opal deposits). Geologiya i geofizika, 2003, V. 44, No. 4, pp. 340-347.

16. Korzhinskii D. S. O ravnovesii pri protsessah mineraloobrazovaniya (Equilibrium of mineral formation). Izvestiya AN SSSR, Ser. Geol, 1965, No. 2, pp. 128-131.

17. Levinson-Lessing F. Yu., Zhemchuzhnyi S. F. Porfirovidnoe stroenie i evtektika (Porhyry-like structure and eutectics). Zap. SPb. Min. o-va. 2 ser, 1906, part 44, No. 1, pp. 244-256.

18. Nikitin A. N. Obrazovanie pezoelektricheskih tekstur v kvartssoderzhaschih gornyh porodah (Formation of piezoelectrical textures in quartz rocks). Fiz. Zemli, 1996, No. 10, pp. 15-21.

19. Povarennyh M. Yu. O prostranstvennoi regulyarnosti («elementarnoi yacheike») gornyh porod (About spatial regularity (elementary cell) of rocks). Proceedings of conference «Biohimicheskie karbonaty antropogenovyh ozer i istochnikov». Perm, 1989, pp. 138-151.

20. Povarennyh M. Yu. K sozdaniyu estestvennoi klassifikatsii gornyh porod na osnove teoretiko-sistemnoi kontseptsii «elementarnyh yacheek» (About creation of natural classification of rocks on basis of theoretical-systematical conception of elementary cells). VIII seminar «Sistema Planeta Zemlya». Moscow: Garmoniya stroeniya Zemli i planet, 2000, pp. 73-83.

21. Povarennyh M. Yu. O frustumatsii (svoistve pervichnoi kuskovatosti, fragmentatsii) gornyh porod i ee vliyanii na ih drobimost' i vozmozhnost' krupnokuskovogo obogascheniya (About frustumation (primary lumpiness, fragmentation) of rocks and influence on their crushing properties and possibility of concentration). Proceedings of annual meeting of RMS. St Petersburg, 2006, pp. 168-176.

22. Povarennyh M. Yu. Ob ustanovlenii novogo svoistva gornyh porod - skrytoi tekstury (New feature of rocks). Doklady RAN, 2008, V. 419, No. 2, pp. 233-236.

23. Povarennyh M. Yu., Beskin S. M. Primenenie sovremennyh tehnicheskih i analiticheskih sredstv vyyavleniya pervichnoi kuskovatosti (frustumatsii ili obrazovaniya «elementarnoi yacheiki») gornyh porod (Application of modern technical and analytical means to determine primary lumpiness (frustumation or formation of elementary cell) of rocks). Proceedings of 1 Russian seminar on technological mineralogy. Petrozavodsk, 2006, pp. 138-145.

24. Povarennyh M. Yu., Zhabin A. G. Frustumatsiya (pervichnaya kuskovatost) gornyh porod kak proyavlenie kvantovaniya-zernistosti gornoporodnogo urovnya prostremeni (Frustumation (primary lumpiness) of rocks as phenomenon of quantification grain structure of mining level). Uralskii geol. Zhurnal, 2007, No. 5 (59), pp. 51-60.

25. Povarennyh M. Yu., Zagubnyi D. G., Korchuganova. N. I. Poiski blagorodnogo opala v Yuzhnoi Avstralii s ispolzovaniem distantsionnyh metodov (Searches of noble opal in South Australia using remote methods). Razv. i ohrana nedr, 2014, No. 7, pp. 31-40.

26. Povarennyh M. Yu., Knotko A. V., Matvienko E. N., Burmistrov A. A., Plechov P. Yu., Luksha V. L. Osobennosti irizatsii $v$ blagorodnyh opalah $v$ svete ih mozaichno-klasternogo (frustumatsionnogo) vnutrennego stroeniya (Features of irization in noble opals in view of their mosaic-cluster (frustumation) internal structure). Doklady RAN, 2016, V. 467, No. 6, pp. 701-703.
27. Povarennyh M. Yu., Matvienko E. N. Razvitie teorii mineralogii i petrografii. Teoretiko-sistemnoe obosnovanie estestvennoi klassifikatsii gornyh porod i postroeniya Periodicheskoi Sistemy Mineralov (Development of theory of mineralogy and petrography. Theoretical-systematic confirmation of natural classification of rocks and establishing of Periodical System of Minerals). Saarbryukken, LAP Lambert, 2014, 117 pp.

28. Povarennyh M. Yu., Matvienko E. N. Novoe makroskopicheskoe svoistvo gornyh porod - frustumatsiya - kak proyavlenie kvantovaniya-zernistosti gornoporodnogo urovnya prostremeni (New macroscopic feature of rocks - frustumation as quantification - grain structure of mining level of prostremya). Prostranstvo i Vremya, 2015, No.3, pp. 327-338.

29. Povarennyh M. Yu., Rassulov V. A., Matvienko E. N. O skrytoi teksture (frustumatsii) naibolee prostyh po mineral'nomu sostavu igenezisu gornyh porod (About hidden texture (frustumation) of the rocks - the simplest by their mineralogical composition and genesis). Mineral. zhurn. (Ukraine), 2014, V. 36, No. 1, pp. 88-100.

30. Popov V. A. Prakticheskaya kristallomorfologiya mineralov (Practical crystal morphology of minerals). Sverdlovsk: USS USSRAS, 1984, 191 pp.

31. Popov V. A. Prakticheskaya geneticheskaya mineralogiya (Practical genetic mineralogy). Ekaterinburg: UB RAS, 2011, 167 pp.

32. Sadovskii M. A. Estestvennaya kuskovatost gornoi porody (Natural lumpiness of rocks). RAS, 1979, V.247, No 4, pp. 829-831.

33. Sadovskii M. A. O raspredelenii razmerov tverdyh otdelnostei (About distribution of sizes of solid varieties). Doklady of USSRAS, 1983, V. 269, No. 1, pp. 69-72.

34. Sadovskii M. A., Bolhovitinov L. G., Pisarenko V. F. O svoistvah diskretnosti gornyh porod (About features of discreteness of rocks). Preprint, 1981, No. 1, pp. 15-28.

35. Samoilovich L. A., Balakirev V. G., Samoilovich S. M. Nekotorye osobennosti mikrostruktury sinteticheskogo i prirodnogo blagorodnogo A-opala (Some features of microstructure of synthetic and natural noble A-opal). Razvedka i ohrana nedr, 1995, No. 3, pp. 23-27.

36. Serdobintseva V. V., Kalinin D. V. i Vosel S. V. Formy kolloidnogo kremnezema, uchastvuyuschie v obrazovanii blagorodnogo opala, i mehanizm okremneniya ego gelevyh kristallov (Forms of colloidal silica participating in formation of noble opal and mechanism of silification of its gel crystals). Geologiya i geofizika, 1999, V. 31, No. 8, pp. 1116-1120.

37. Sustavov O. A. Struktury kristallizatsii kvartsa v zhilnyh polostyah (Structures of crystallization of quartz in vein voids). Uralskaya mineralogicheskaya shkola 2005. Ekaterinburg, UGGU, 2005, 93 pp.

38. Fersman A. E. Elementy razgranicheniya dvuh odnovremenno kristallizuyuschihsya veschestv (Elements of division of two simultaneously crystallizing substances). Doklady AN SSSR, seriya A, 1922, December-January.

39. Choudhary G. Gem News International: An interesting opal. Gems \& Gemology. 2008. Vol. 44, No. 2, pp. 172-174.

40. Darragh P. J., Gaskin A. I., Terrel B.C., Sanders J.V. Origin of precious opal. Nature. 1966, V. 204. № 5018, pp. 13-16.

41. Derjiagin B.V. \& Landau L.D. Theory of stability of strongly charged lyophobic sols. Acta Physicochim. USSR, 1941, V. 14 , pp. 633-662.

42. Flörke O.W., Gaetsch H., Martn B., Roller K. and Wirth R. Nomenclature of micro- and non-crystalline silica minerals, based on structure and microstructure. N. Jahr. fur Min.-Abh. 1991, 163, pp. 19-42.

43. Fritsch E., Rondeau B. Gem News International: Rare optical phenomenon in play-of-color opal // Gems \& Gemology, 2009, V. 45, No. 2, pp. 147-148. 
44. Fritsch E., Rondeau B., Ostroumov M., Lasnier B., Marie A.-M., Barreau A., Wery J., Connouй J., Lefrant S. Découvertes récentes sur l'opale. Rev. de Gemmologie a.f.g. 1999. No. 138/139, pp. 34-40.

45. Fritsch E., Gaillou E. Ostroumov M., Rondeau B., Devouard B. and Barreau A. Relationship between nanostructure and optical absorption in fibrous pink opals from Mexico and Peru. Eur. Jour. Miner. 2004, 16, pp. 743-752.

46. Gaillou E. Relation entre Nanostructure, PropriétésPhysiques et Mode de Formation des Opales A et CT. PhD thesis, University of Nantes, 2006, 278 p.

47. Gaillou E., Delaunay A., Rondeau B., Bouhnik-le Coz M., Fritsch E., Cornen G., Monnier C. The geochemistry of opals as evidence of their origin. Ore Geology Reviews. 2008a, V. 34, pp. 113-126.

48. Gaillou E., Fritsch E., Rondeau B., Aguilar-Reyes B., Barreau A., Ostroumov M., Post J. Common gem opal: An investigation of micro- to nano-structure. Am. Miner. 2008b, Vol. 93, pp. 1865-1873.

49. Gauthier J.-P., Mazzero F., Mandaba Y., Fritsch E. L'opale d'Ethiopie: Gemmologie ordinaire et caractŭristiques exceptionnelles. Revue de Gemmologie a.f.g. 2004, No. 149, pp. 15-23.

50. Gregor M. Opal mineralization of western Carpathians: mineralogy and petrogenesis. Comenius Univ. Bratislava. Fac. Nat. Sc. Geol. Inst. Advisor: doc. RNDr. Pavel Uher, PHd, 2011, 178 p.

51. Jones J. D., Segnit E. R. The occurrence and formation of opal at Coober Pedy and Andamooka. Australian Journal Sci. 1996. V. 29, No. 5, pp. 129-133.

52. England J. L. Statistical physics of self-replication. J. Chem. Phys. 139, 121923 (2013); doi: 10.1063/1.4818538.

53. Koivula J. I., Kammerling R. C., Fritsch E., Eds. Gem News: Opal from Ethiopia. Gems \& Gemology. 1994. Vol. 30, No. 1, pp. 52-53.

54. Mazzero F., Gauthier J.-P., Rondeau B., Fritsch E., Bekele E. Nouveau gisement d'opales d'Ethiopie dans la Province du Welo: Preminres informations. Revue de Gemmologie a.f.g. 2009, No. 167, pp. 4-5.
55. Nicolis G., Prigogine I. Self-Organization in NonEquilibrium Systems: From Dissipative Structures to Order Through Fluctuations. New York: J. Willey \& Sons. 1977, 347 p.

56. Povarennykh M. Yu., Rassulov V. S., Lobzova R. V. Frustumation (fragmentation, lumpiness, «rock unit cells» formation) - the first discovery of the rock universal property. Proc. XI Int. Cong. Mathem. Geol. «Quantitative Geology from Multiple Sources». Liege. 2006. CD-ROM D/2006/0480/31.

57. Povarennykh M. Yur., Matvienko E. N. Opals: Australian vs African. Russian Diamonds \& Jewelry. Autumn. 2015, pp. 12-16.

58. Povarennykh M. Yur., Matvienko E.N. Description of precious opals diversity from S. Australia (Coober Pedy deposit) as superfine-grained rocks according to their different frustumational inner fabric. Proc. Int. Conf. Sofia, 2015, pp. 173-184.

59. Reusch E. Ueber einen Hydrophan von Czerwenitza. Annalen der Physik. 1865, V. 200, No. 3, pp. 431-448.

60. Rey P. F. Opalisation of the Great Artesian Basin (central Australia): an Australian story with a Martian twist. Australian Journ. Earth Sc. 2013, 60, pp. 291-314.

61. Rondeau B., Mazzero F., Bekele E., Gauthier J.-P., Fritsch E. Gem News International: New play-of-color opal from Welo, Ethiopia. Gems \& Gemology. 2009, V. 45, No. 1, pp. 59-60.

62. Rondeau B., Fritsch E., Mazzero F., Gauthier J.-P., Cenki-Tok B., Bekele E., and Gaillou E. Play-of-color opal from Wegel Tena, Wollo Province, Ethiopia. Gems \& Gemology. 2010, V. 46, No. 2, pp. 90-105.

63. Sanders J. V. Colour of Precious Opal. Nature. 1964, No. 204, pp. 1151-1153.

64. Smith K. L. Opals from Opal Butte, Oregon. Gems \& Gemology. 1988. V. 24, No. 4, pp. 229-236.

65. Spencer R. J., Levinson A. A., Koivula J. I. Opal from Querŭtaro, Mexico: Fluid inclusions study. Gems \& Gemology. 1992. Vol. 28, No. 1, pp. 28-34.

66. Verwey F. I. W. \& Overbeek J. Th. Theory of stability of lyophobic colloids. Amsterdam. 1948, 287 p. 